\title{
Jordanian Students' Perceptions, Understanding, and Knowledge towards the Role of Internet in Learning "Englishes" and English Language Skills
}

\author{
Raeda Tartory ${ }^{1}$ \\ ${ }^{1}$ Department of English Language and Literature, Faculty of Arts and Sciences, Al-Ahliyya Amman University, \\ Amman, Jordan \\ Correspondence: Raeda Tartory, Department of English Language and Literature, Faculty of Arts and Sciences, \\ Al-Ahliyya Amman University, Amman, Jordan. E-mail: r.tartory@gmail.com
}

Received: August 13, 2020

Accepted: August 28, 2020

Online Published: September 9, 2020

doi: 10.5539/elt.v13n10p38

URL: https://doi.org/10.5539/elt.v13n10p38

\begin{abstract}
The study aims to identify the perceptions of university students of Jordan towards the role of internet in learning and improving their understanding of Englishes and English language skills. The study followed a cross-sectional study design and a structured questionnaire was used to collect data from 181 university level students studying in different public and private sector universities. Descriptive statistics and regression analysis were used to present the findings. Results of the analysis indicated marked positive perceptions of students towards the role of internet in learning Englishes and language skills. Majority of students, considered internet as a useful tool and a learning platform that could help them in understanding and identifying the differences between British and American Englishes. Besides, most of the responses indicated an insignificant relation between students' perceptions of World Englishes and the role of internet. Jordanian University students discovered the potential importance of internet in learning English language skills and World Englishes and, therefore, internet is considered helpful in developing their self-learning skills, self-confidence, and it also influences their learning attitude, and strengthens their linguistic skills.
\end{abstract}

Keywords: communication, English Language, Englishes, Internet, knowledge, language skills

\section{Introduction}

The field of World Englishes (WE) is extensive and deals with the worldwide spread of English language as the lingua franca with respect to its linguistic, pedagogical, literary, formal and functional variations, different sociolinguistic context, varieties and ranges of creation in both Western and non-Western regions (Kachru, 1997). For instance, Hickey (2010) in his book discussed the English language used in Ireland, and the variations developed in the language across various regions including northern, south-west and western parts of the country. According to him, these are considerable variations as shown by the linguistic characteristics of each variation. These characteristics help in developing a linguistic area across Ireland (Hickey, 1999). Another reason behind the linguistic variation of the language is based on the historical roots of language that are particularly associated with the demographic characteristics which justify the concept behind 'Englishes' (Hickey, 2010). It is important to note that the varieties found in the English language across Ireland were developed in the mid of early seventeenth and late nineteenth century, also known as 'the Colonial Period' which significantly contributed in the spread of English across various regions of the world (Hickey, 2010).

According to Kachru (1992), the sociolinguistic profiles of English are divided into three circles. These circles represent the types of language spread, different patterns of language acquisition, and the functional view of English in the presence of diverse cultures. In this context, the concept of WE is much broader than the sheer description and analysis of regional and national varieties of English language. Several literary resources such as Kirkpatrick (2010) and Kachru, Kachru and Nelson (2006) suggested that different ideological, theoretical, and applied issues that are related to English are now being investigated in terms of different functional domains such as the academia, commerce, ideology and attitudes related to language and policy and planning that have developed variations in English across different domains. 
The diversity of English language makes us realize its plurality and at the same time, makes it necessary to identify the implications of these varieties. In the ongoing global development, language learners must be equipped with better knowledge of using their language for effective communications across language varieties. The most promising way to equip learners with such skills is to develop a thorough awareness regarding the existence of Englishes, other than the variety of English language spoken at different platforms such as classrooms or media channels (Galloway, 2017). For Canagarajah (2006), learners need not to gain expertise in varieties of English language, but they need to remain prepared with respect to different sociolinguistic, metalinguistic, and attitudinal characteristics of the English language in order to negotiate the differences found in language.

Sarnoff (1970) defined attitude as the disposition to react favourably or unfavourably to a class of subjects. Ito and Cacioppo (2007), on the other hand, defined attitude as the enduring predisposition of an individual to respond to a certain stimulus. However, in the linguistic context, the attitude might be defined as an umbrella term for individual attitude towards variety of specific language and the associated individual preferences, language teaching, learning situation and language groups and communities (Galloway, 2017). An individual attitude towards language is considerable as it creates a significant impact on how people view each other. Perception, on the other hand, refers to "a belief or opinion held by people based on how things seem" (Cambridge Dictionary, n.d.). It is further termed as a mental image or concept (Merriam Webster, n.d.) that develops during meaningful interactions. According to the Oxford Learner's Dictionary (2005), perception functions as an initiative insight or an impression based on such understanding, opinion or belief. Both language attitudes and perceptions are different terms, as an individual's perception may affect his attitude towards language varieties and native language speakers (Al-Dosari, 2011). Additionally, variations in the language help in developing our perceptions about speakers of the same language, despite their different national and geographical backgrounds.

The existing sociolinguistic landscape of English also indicates the value of raising the awareness in language learners related to linguistic diversity of the Englishes of the modern era, in spite of the variety characterized as the dominant instructional model. WE, in this perspective, outlines the effects of lack of awareness regarding the varieties of English language which may adversely affect the attitude of language learners towards different varieties of the English, which, in the long run, might affect learner's confidence in communicating and interacting with people who speak different varieties of English (Matsuura, Chiba, \& Fujieda 1999; Smith \& Nelson, 2019). Raising such an awareness among learners is possible if they are exposed to Englishes through multiple resources, as for instance; Galloway \& Rose (2018) conducted a study with an aim to develop students' awareness of Global Englishes in a Japanese language classroom. Students were assigned a task to select a regional variety of English and libraries, internet-based learning resources, audio recordings etc. were used to collect information regarding the chosen language. Findings indicated that by utilizing the above resources, students were able to collect information regarding the Japanese English, Malaysian English, Scottish English, Australian English, Philippine English, etc. Seargeant and Tagg (2011), on the other hand, identified that Thai speakers faced several difficulties in communicating via online social network due to complex understanding of world Englishes. Anwar et al. (2020) conducted a study on the preferences of Indonesian students regarding the benefits of learning Englishes. Findings of the study indicated that English serves as the gateway to understanding and knowing native speakers' language and their cultural norms. This perspective echoed the worldwide spread of English.

To this end, internet serves as the most valuable source that may assist learners, while allowing them to explore, communicate and learn about the diversity of English language through online materials, books, newspapers, videos, social media platforms, etc. Internet has further allowed students to access different information related to the language across the globe (Baik \& Shim, 2002). Social, cultural, political, economic and geological information of different countries can also be accessed, while observing the linguistic and pedagogical differences in the target language. Students may further access to different newspapers and daily reports from official news websites of each region (Matsuda, 2012). Such experiences are valuable as they allow the learners to increase their knowledge of the target language (Singhal, 1997).

Costley (2014) added that technology has a positive effect on language learning as it increases the engagement level of learners and maximizes their capacity to grab information. Technology is also useful in enhancing the learning experience of students, and provides them the opportunity to engage with other learners who belong to different linguistic and cultural backgrounds. The study added that use of such technology deepens learners' engagement in the learning process (Gilakjani, 2017). Certainly, it is very important for language learners, as it is the most basic and initial exposure to the language available to them. This uninterrupted exposure of knowledge motivates learner to adapt to the learning process conveniently.

The rationale behind focusing on the concept of perception rather than attitude is that the individual's perception towards the concept of WE develop their attitude to accept the varieties of English language. A positive perception 
may stimulate positive attitude towards learning, accepting and understanding the language and vice versa. The concept of a student's perception and its role in language learning have been studied by various researchers. For instance, Noels, Clément and Pelletier (2001) correlated learners' perception with their intrinsic or extrinsic motivation of language learning, whereas Yan and Horwitz (2008) identified the association between learner's perceptions and their level of anxiety with respect to foreign language learning. Yoshida, (2008) focused on students' perceptions regarding language learning and its association with the desire to participate in the learning process, and Tokumoto and Shibata (2011) investigated the students' perceptions of learning English as a second language in South Korea and Japan. According to the study, most of the Japanese students were unable to accept their accents, since majority of the population in these countries followed the native approach of language. Also, most of them self-doubted their intelligence, despite being taught by both native and non-native English speakers; however, Korean students showed positive perceptions regarding their accents of second language. Following this, the importance of students' perceptions is obvious and requires further research (Kissau, Algozzine, \& Yon, 2012).

\subsection{Study Aim and Significance}

Therefore, the current study aims to examine the perceptions of Jordanian university students regarding the role of internet in developing their understanding of World Englishes, and in improving their English language skills. The current study is significant as findings of the study may help language learners in identifying the usefulness of internet in learning World Englishes. Contributions of this study are important as they may bring about important changes in the policies related to the academic curriculum which may be redesigned to encourage students learn through internet. English language teachers may be highly benefited from this study, as the provided information will help teachers in introducing new learning methods; for example, use of important e-learning resources in teaching and learning that can be used for language development. The study is further important for teachers, as the issues outlined by the study provides a realistic view of the existing problems faced by both students and teachers and would help teachers develop a positive perception of learners towards learning World Englishes through internet. Finally, academicians struggling to develop a firm understanding of Englishes along with the development of English language skills may be benefited from this study as it highlights useful information to overcome issues related to language learning.

\subsection{Research Questions}

Considering the aim of this study, following questions will be answered in this study:

a) With respect to the perception of Jordanian university students, what is the role of internet in improving their understanding of World Englishes?

b) To what extent Jordanian university students consider internet as an important source to be used for improving their English language skills?

\section{Literature Review}

\subsection{Historical Aspect of World Englishes (WE)}

The development of the concept of world Englishes is attributed to the emergence of different varieties of English language (Widdowson, 1997). These varieties of English language are determined through their functions, which, in a broader aspect, identify the role and feature of the word Englishes. Some of these varieties include Englishes of business and computer mediated and Englishes of the pop culture and academia. The concept has also led to the use of new linguistic resources to learn trans-lingual franca English (Kirkpatrick, 2010).

Kachru (2011) provided important classifications of Englishes. According to his study, Englishes is categorized under three types of circles. The first type is the inner circle which served as the foundation of the increased variety of Englishes. As English language speakers from England reached to the colonies of New Zealand, Australia, Canada, and North America, they infused their historical and traditional language which has its sociolinguistic foundations in the regions where English is now used as a native language. These regions include Australia, United Kingdom, Ireland, Canada, United States, New Zealand and the Caribbean territories. The second type is the outer circle: this type was developed mainly by African and American colonies for trading purpose. Englishes of the outer circle was further influenced by the languages used by the indigenous people due to the increased contact between locals and foreigners.

The third circle identified by Kachru (2011) is known as the expanding circle, which was generally found in countries where English was traditionally learned as the foreign language and was limited in terms of its institutional and administrative role. Countries in the expanding circle use English as a medium of international communication and includes most of the population that is not found both in the inner or the outer circle. Jordan, China, Japan, Indonesia, 
Korea, Russia, Brazil etc. are some of the countries that belong to the expanding circle of Englishes (Lee \& Jun, 2016).

Hamdan and Hatab (2009) investigated the development of English in the Jordanian context, and provided detailed analysis regarding the ranges and depth of English used in Jordan. According to the study, use of English language has been apparent and increased with the passage of time on account of its greater usage in two important domains: education and media. In addition, the changing status of the English language is attributed to two important sources. The first source is the job advertisements published in the Jordanian newspapers in the past two decades i.e. 1985 to 2005. The second source includes the documents published by the Ministry of Education since the development of Jordan as the political figure under the 1921 British mandate. However, the American and British language centers operating in Jordan are the major contributors of the type of English articulated by Jordanian population. Also, local English publications are mainly pedagogical in nature (Drbseh, 2013).

Kilickaya (2009) in her study raised an important concern regarding the English taught to people belonging to the expanding circle. According to the study, one of the major concerns in teaching World Englishes should be the appropriate selection of English needed to be taught to the expanding circle. For instance, when teaching English to Turkish students enrolled in the educational institution of USA, it is preferable to teach American English to facilitate cross cultural communication. This is further helpful in developing students' understanding of different accents and varieties of English language. Widdowson (1994) supported the argument and indicated that several bilingual users of English, specifically those belonging to the expanding circle, acquire English language through education which makes it important to develop a standard form of English to ensure that individuals of the expanding circle acquire a uniform English. Drbseh (2013) outlined the use of English in the private education of Jordan and highlighted that English in Jordan has been reinforced through two foreign language institutions: The British Council and the American Language Center. However, British council has been regarded as the promulgator of English in Jordan, as it offered English language courses to students enrolled in any educational program. Likewise, American Language Centre has been providing language education to students for quite a long time.

Todd (2006) provided an important suggestion regarding learning and teaching English in Thailand, and stated that English language teaching and learning must be based on the appropriate pedagogy, where educational institutions should follow a suitable ideology of English as an International Language (EIL). He further emphasized that the English teaching and learning should follow and idealized approach of EIL to establish learning and teaching on both practical and theoretical grounds. In theoretical perspective, language learners must be aware of socio-political and sociolinguistic profiles of English which include a proper distinction with respect to the use of English language in a multilingual or monolingual society, the criteria of standard English, the consequences leading towards the spread of English, etc.

Mahboob (2013) conducted a study to identify how Saudi English is different from other Englishes. To identify the differences, a text book was analyzed. Findings of the study revealed that Saudi English is different from the standard English with respect to the use of different grammatical structures. These variations were based on the use of articles, tense markers, variations in marking subject-verb agreement and number i.e. singular/plural '-s'. Consider following sentences as an example 1) Nehal got off and Porter carried his bag into the building 2) She is a keen tennis player, and she also like swimming. In the first example, the writer preferred null article over indefinite article, while in the second example, the writer failed to mark 'like' with '-s'.

A more detailed analysis of the concept of Englishes has been provided in different studies. For instance, Cheshire et al. (2007) identified the relativized techniques found in the local dialects of English in England. Another such example includes the use of relativizers such as 'what' and 'as' that usually occur in the non-standard varieties. Peitsara and Vasko (2002) provided an important knowledge in this regard, according to which, being a relativizer is an obsolescent term and is rarely used in the Suffolk, while it is comparatively dominant in the South West. In contrast to this, the use of what, being a zero relativizer with an animate antecedent, is quite robust. The study of Herrmann (2003) further identified that approximately $10 \%$ relativizers are commonly used as both subject and object in reading in East Anglian and South West.

Sevinj (2015) provided further information regarding the variations found in British English on account of the grammatical and lexical characters such as chap (boy), dickey (bird), fellow (young man), etc. in the standard English (SE). It has been recognized as the speech of upper-class people of London and contains Saxon elements in it. In contrast to this, the pronunciation of poor-class people is known as Cockney accent which also contains some Saxon elements. This classification is based on the social aspects of language differences. In contrast to this, the regional dialect of English includes all the new words used in the social life of these places. It is important to note that due to 
the difference in language, the dialect of one place is difficult to understand by the people who live in some other place (Sevinj, 2015).

Continuing the idea further, Hickey (n.d.) focused on the sociolinguistic variations in the English used in Ireland and Britain. The study outlines that the main reason behind these differences is the time duration since the English language has been used in both countries. Since English has been the native language for centuries in both the regions, variations in language are likely to appear in both countries. These social, linguistic and geographical factors along with those provided by the above-mentioned studies are some of the historical factors that resulted in the development of varieties in the English language (Krickpatrick, 2010). Ugoretz (2016) underlined the difference between the standard English (SE) as well as the Chinese English. According to the study, Chinese English is very specific in following certain rules of syntax and lexical items of SE that are highly understandable to native speakers. Despite of its high similarity, Chinese English is not accepted presently as a valid national variety of WE. The study further added that Chinese English is referred as the English which is being used in China, and consists of SE fundamentals, and is recognized as English with Chinese characteristics.

Alomoush, (2019) explored the use of linguistic landscape approach to analyze the changes produced in English language with respect to its use in Jordan. The investigations were carried out by using the global approach, according to which English language tends to develop changes depending upon communities, regions and circumstances in which it is used. Results indicated that most of the English words used in Jordan are either the complete translations of Arabic or serves as the combined brand name and monolingual instructions. These variations are often appealing to children who are taught with the required knowledge and skills that are essential for communication and interaction in English.

Montes (2016) underlined some important aspects of the Brazilian variety of English, which makes a creative usage of the language by borrowing some loanwords of English and use them in Brazilian Portuguese (BP). According to the study, many times English loanwords are utilized by altering their phonology, lexical meaning and the ways these words are being used.

\subsection{World Englishes and Learning English as a Second Language (ESL) through Internet}

The emerging development in IT sector has provided several opportunities for learning and development. Despite the fact that English is widely taught all over the world, the use of internet for learning English has not been supported in many regions. According to Singhal (1997), the use of internet increases the use of English language and, thus, facilitates the acquisition of foreign language. This emphasizes the need to encourage the use of internet in classrooms, to help learners gain exposure to different language learning sources available on the online platforms. Also, despite the understanding that internet serves as a good tool for language learning, students are still dependent on different educationalists, teachers, practitioners and decision makers (Jamalifar \& Chalak, 2014). Wiburg and Butler-Pascoe (2002) supported the idea of Singhal (1997) and indicated that the usability of internet promotes communication in English in real life situations.

Several researchers identified that the use of internet is favorable as it provides several learning opportunities to ESL learners, on account of the online availability of various resources (Cahyono \& Mutiaraningrum, 2016; Smith, 1992). Baik and Shim (2002) conducted a study to identify the use of internet in developing learning materials that are subjective to world Englishes. The study was specifically centered on the Korean students of English. The entire course was developed through different online learning resources and consisted of sample speeches available from all the three circles. Overall duration of the course was 14 weeks. Findings of the study indicated that the online course was successful in expanding students' knowledge of world Englishes, and helped them in the identification of syntax and lexical differences of Englishes based on its usage in different areas.

Students' use of internet for learning Englishes is further supported by Smith (1992) which was cited in the study of Kachru (2011), that internet and media play a significant role in providing individual exposure to varieties of English language. The study added that such an exposure results in the development of accommodation strategies for the variations in lexico-grammar, accent, and discourse. The role of internet is critical, as the online platforms are flooded with different types of published dictionaries that are useful in the identification of different varieties of English. For instance, Encarta World English Dictionary published in 1999 consisted of the English words spoken in East Africa, Hawaii, South Africa, Malaysia, Singapore, Hong Kong, South Asia, UK Black English, and US African American English. Another example includes the Macquarie Dictionary, which, when published in 1997, consisted of lexical items extracted from the South East Asian Englishes (Maftoon \& Esfandiari, 2013).

In the view of Al-Kadi and Ahmed (2018), internet served as one of the dominant factors that produced a new variety of English language which is different from that of the standard English. This pinpoints the changes that have been developed in the written and spoken English from 1990 onwards. For instance, researchers like Lyddy et al. (2014) 
and Abu Sa'aleek (2015) outlined the historical change emerged in the use of English language in various online platforms and analyzed the use of electronic language in the formal context. Besides, researchers have now been using different terms for the English used on the electronic platforms and is termed as 'electronic language' (Collot \& Belmore, 1996), 'internet language' (Thurlow, 2001), 'electronic discourse' (Davis \& Brewer, 1997), 'computer mediated communication' (Herring, 1996) etc. All these terms represent a unique variety of English which is in general known as the electronic English.

Sun (2010) in his study studied the distinctive and common patterns of lexicon and word formation shared by the internet English with other varieties of the English language. However, four common characteristics were found in the new terms which include brevity, creativity, popularity and words consisting of rich metaphorical meanings. For Crystal (2011), this language change involves the change in vocabulary, grammar, pragmatics, orthography, style and pragmatics.

Internet platforms have been widely used in the language learning and teaching. Its usage has further given rise to the development and usage of new words. Syawal, Patahuddin and Nasrullah (2017) provided the contradicting aspects in this regard, and identified the negative effects of internet on the behavior of language learners. The study was based on Indonesian students of the Muhammadiyah University. Findings of the study indicated that though students preferred internet as an important learning source; however, it failed to improve the creative and self-learning abilities of students. Matsuda (2012) added that the use of internet is not only limited to the availability of teaching and learning materials for English as a second language (ESL), and can also be used for learning English as a foreign language (EFL).

Online available resources such as English newspapers belonging to the inner, outer and the expanding circles can be easily used as an authentic source of reading materials or as the base for classroom discussions related to ESL learning. Other similar resources include short audio and visual clips issued by different broadcasting websites, including those available on YouTube which ultimately expose students to a variety of English used in different regions. Similarly, students through online available learning resources may compare and contrast available articles on a topic to identify the linguistic differences in them.

Farrell and Martin (2009) in their study suggested additional websites, such as International Corpus of English which serve as a useful source of learning varieties of English through different regional and national resources. Students may further visit World-Newspapers that provides access to different newspapers published globally. This may further promote the intercultural communications, while imitating the language of different broadcasters speaking on online channels.

\subsection{Influence of Student's Attitude in Learning World Englishes through Internet}

Another study conducted by Heirati and Alashti (2015) explored the attitude of Iranian English students of the short-term education center towards the use of internet for language learning. A comparative analysis between the attitude of male and female participants was further conducted. Findings of the study identified an insignificant difference between the attitudes of male and female language learners. In addition, most of the learners showed positive attitude towards the use of internet for language learning. Also, majority students showed their agreement that internet is potentially helpful in providing them an appropriate learning environment in comparison with their previous learning environment. The study, therefore, concluded that internet serve as an effective source of language learning and, thus, contributes in improving students' language skills.

The study of Aydin (2007) further investigated the attitude of EFL learners towards the use of internet for foreign language learning. Relationship between learner's attitude, gender and age were also investigated. Findings of the study identified positive attitude of EFL learners towards the use of internet for language learning. Moreover, male respondents had more positive attitudes towards the use of internet for language learning, and considered it vital for cultural exchange. However, most of the female respondents indicated that internet is useful in providing the prepared knowledge.

Rousseau (2012) conducted a study to identify the impact of high awareness of World Englishes on the language attitudes of university students of Korea. Data was collected through direct and indirect attitudinal measurement. Direct attitudinal measurement was carried out through a point Likert scale survey, while indirect attitudinal measurements were held through verbal guise test. In the later part of data collection, recordings of different speakers from six varieties of English language: American, British, Saudi, Chinese, Japanese and Korean English were included. Findings of the study indicated statistically significant and positive changes in the attitudes of Korean students towards Chinese, British, Japanese and Korean English; however, no statistically significant change of attitude was identified in Saudi Students. Moreover, negative and significant change in attitude towards the American 
speakers was detected in Korean students. Also, most of the participants showed their agreement in speaking English with the non-native speakers.

Tahmasbi, Hashemifardnia and Namaziandost (2019) in their study identified the extent to which Iranian EFL learners positioned in the expanding circle of English users. It further identified their attitudes towards World Englishes WE and Standard English (SE), along with their level of ownership over English. Findings of the study indicated that most of the students showed positive attitude for World Englishes as the highest mean value was obtained for the phrase that "English is going everywhere, so we should respect all English varieties." They further expressed high willingness in calling English as an important property of EFL learners. However, no negative views of participants were identified towards either SE or WE. According to Lee (2019), teachers play an important role in influencing students' attitude towards varieties of English language. Findings of the study identified instructional support and learning tasks supplemented by a teacher help in shaping students' attitude towards the varieties of English. The above review of literature clearly indicates that the concept of World Englishes is common, however, only limited studies have focused on the student's perception of learning Englishes through internet.

\subsection{Role of Internet in Learning Writing, Reading, Listening, Pronunciation, Grammar and Spelling}

Students' ability to identify the differences in world Englishes is further dependent on teachers' interpersonal skills and their familiarity with different internet-based techniques used for developing language skills. Cahyono and Mutiaraningrum (2016) conducted an important study and investigated the familiarity level of EFL teachers with the internet-based techniques for developing writing skills of students. The study further identified teachers' opinions regarding the usage of these techniques for teaching and learning. Findings of the study indicated that Indonesian EFL teachers have positive preferences regarding the use of internet-based techniques for language learning, as it helped students in improving English writing skills. The study concluded that the development of ICT is, therefore, critical in developing student's ESL skills.

Tamandani and Jahanshahi (2016) conducted a study to identify the use of e-learning tools that are helpful in improving English language skills of non-native learners. According to the study, e-learning platforms provide different diverse resources that are helpful in improving students' English language skills: reading, writing, speaking and listening. Certain highly useful tools were highlighted in this study. First includes the Longman Dictionary of Contemporary English (LDOCE) 5th Version, which is an amazing tool which incorporates computer database with pictures and sounds. The user may get access to different features which includes a) Word pronunciation b) Grammar lessons c) Phonetic transcription and syllable division d) Grammar lessons e) Exercises f) Vocabulary trainer. In addition, students may get access to different internet-based materials available online such as conference papers, books, articles, courses, etc. In order to improve English speaking skills, students can use YouTube which provides wider access to the global community for the available linguistic content including movie trailers, music videos, video or TV clips, etc. and various worldwide media communities such as BBC, Vevo, CBS, Hulu etc. Another similar application is Skype which can be used to conduct video conference calls, and serves as an important medium to take part in online foreign language classes. SMART board is another unique platform that can be used to improve students' English reading and comprehension skills.

Aliyev and Ismayilova (2017) provided a unique knowledge regarding the use of online technology to improve students' English language writing skills. According to the study, online available movies serve as an authentic source to develop students' exposure to real language, which helps in improving students understanding of foreign culture that leads to the improvements in listening, speaking, reading, and essay writing skills (Ergenekon, 2016). Aliyev and Ismayilova (2017) chose two movies namely "Ratatouille" and "Blood Diamond", as these were related to the writing content in the unit book. Students watched the two movies and afterwards, they were given a questionnaire which consisted of questions related to the movies. Findings of the study indicated a significant improvement in students' writing skills, specifically among those who had the exposure to online movies.

Benmeddah (2017) examined the role of ICT in improving students' speaking skills. Online sources such as Skype, Facebook, YouTube were used during the learning process. Findings of the study indicated that the use of ICT resources made it easy for students to understand different words used in the English language. In further enabled the chances of meaningful interactions of students with native speakers which motivated learners for further learning. This has also positively influenced the listening skills of students, as they were motivated to communicate effectively in the native language of the foreign speaker. Similarly, Noytim (2010) investigated the potential value of Weblogs in improving students' English language writing skills. Findings of the study indicated that Weblogs are effective in improving students' skills of English language. It further encouraged learners in self-expression of their thoughts, and developed a sense of ownership in writers which encouraged them to write more effectively. Mustafa, Sai and Razak (2012) investigated the usefulness of internet in improving students' English language vocabulary. Learners were 
provided with online reading tasks for developing vocabulary. Findings of the study indicated high learner engagement in reading the text online, and revealed ease in learning English through online sources. Besides, much improvements were observed in students' skills of vocabulary learning, as most of the students enjoy online learning resources. Molchanova (2015) pinpointed that the use of online learning materials helps in solving a number of educational tasks, some of them include listening skills, vocabulary building, reading and writing skills, which apparently motivate learners to learn a language. Petrovskaya and Rymanova's (2014) further showed significant improvement in the English language communication skills of learners when they used modern information technologies, as most of the students felt motivated in learning English language and its varieties.

\section{Materials and Methods}

\subsection{Research Design}

A cross-sectional quantitative research design was used to examine the role of internet in developing and improving understanding of Jordanian university students towards world Englishes and English language skills. The purpose of using a cross-sectional study was that it refers to the analysis of data collected from a specific population at one specific point of time. In this regard, this study measured the role that internet plays in enhancing the knowledge of Jordanian university students regarding the existence of varieties of English and also how it improves their English language skills.

\subsection{Sampling Technique}

A random sampling technique was applied to recruit the targeted audience in this study. This technique was used to randomly select Jordanian university students without any bias. The technique helped the researcher to select participant regardless of any restriction or predefined criteria.

In this regard, all students enrolled in Jordanian universities were eligible to take part in this study. As the study focused on the identification of Jordanian students' perceptions regarding the role of internet in their understanding and knowledge of Englishes and English skills, university students of Jordan were the targeted population.

Considering the limitations of time and resource, this study recruited a sample of 241 male and female university students enrolled in a number of public and private Jordanian universities. The selection of these students was based on their major subjects: English; English Language and Literature and English/Arabic Translation. The inclusion criteria further included students that are enrolled either in BA, MA or graduated programs of higher education. However, major preference was given to students who were skilled in using internet and other online platforms.

\subsection{Data Collection and Instruments}

A primary data collection approach was used to collect information from the targeted sample via self-structured close-ended questionnaire. The questionnaire consisted of three major sections: Section A contained demographic related questions, Section B contained questions related to the role of internet and its assistance in increasing knowledge of Englishes $(\mathrm{n}=10)$ and Section $\mathrm{C}$ contained questions related to the role of internet and its assistance in improving students' English language skills $(\mathrm{n}=10)$. The questionnaire was sent to students to be filled in electronically using WhatsApp and Messenger.

The researcher ensured that none of the questions framed in the questionnaire will disrespect the morals and ethics of students. In response, 241 questionnaires were received from which 60 questionnaires were excluded since they contained incomplete responses. Therefore, the final study sample, to be used for statistical analysis consisted of 181 students.

\subsection{Validity and Reliability}

A team of 2 experts cross-checked the questionnaire for making corrections and amendments in it before it was distributed to the study participants. In the screening process, each item of the questionnaire was cross-checked and was matched with the objective of the study to ensure that both questionnaire items and objectives are interlinked with each other. Some items of the questionnaire were similar to the questionnaire items used by $\mathrm{Yu}$ (2010). Few corrections were made in the questionnaire according to the suggestions to confirm the validity of the questionnaire at the time of data analysis.

On the other hand, a reliability test was performed through Cronbach alpha to measure the reliability of questionnaire. In this regard, a pilot test using a sample of 20 participants was performed to measure the reliability of the questionnaire by keeping the baseline of Cronbach alpha at standard value of 0.70 . Normally, the acceptable range for the Cronbach's alpha is 0.70 , which means that items higher or equal to this value is in its acceptable or satisfactory range. The Cronbach alpha value for 20 items present in sections B and C shows $83.7 \%$ reliability of the questionnaire. 


\subsection{Analysis}

The study conducted a cross-sectional analysis via descriptive statistics, multiple regression analysis and Pearson correlation analysis via Statistical Package for Social Sciences (SPSS) version 22. The following tests were conducted to examine the relationship and impact of internet in learning Englishes and English language skills in Jordanian university students.

\subsection{Ethical Considerations}

The study was approved by the Institutional Review Board of the selected universities. Besides, an informed consent was obtained from participants regarding their participation in this study. Information related to the participants was kept confidential to comply with ethical practices of the study.

\section{Results}

This section provides students' perceptions regarding the role of internet in learning English language varieties and skills. Table 1 presents demographic characteristics of university students based on their gender, age, university year, educational level, and nationality. Out of 181 university students, $75.7 \%$ students were females and $24.3 \%$ students were males. $66.3 \%$ students aged between $20-24$ years old, followed by $13.3 \%$ students aged between $25-28$ years, $12.7 \%$ students were between $29-32$ years, and $7.7 \%$ students were of $33+$ years. $54.7 \%$ students were enrolled in the 4 th year of educational program, followed by $18.2 \%$ students enrolled in 3rd year, $14.4 \%$ students in 2 nd year, and $12.7 \%$ students in 1 st year of university education. $61.3 \%$ students were enrolled in graduation program, $27.6 \%$ students were enrolled in post-graduate program, and $11.1 \%$ in master program. $80.1 \%$ students were Jordanian students and $19.3 \%$ students were Non-Jordanian students.

Table 1. Demographics

\begin{tabular}{|c|c|c|c|}
\hline \multicolumn{4}{|c|}{ Gender } \\
\hline & & Frequency & Percent \\
\hline \multirow[t]{3}{*}{ Valid } & Male & 44 & $24.3 \%$ \\
\hline & Female & 137 & $75.7 \%$ \\
\hline & Total & 181 & 100.0 \\
\hline \multicolumn{4}{|c|}{ Age } \\
\hline & & quency & Percent \\
\hline \multirow[t]{5}{*}{ Valid } & $20-24$ & 120 & $66.3 \%$ \\
\hline & $25-28$ & 24 & $13.3 \%$ \\
\hline & $29-32$ & 23 & $12.7 \%$ \\
\hline & $33+$ & 14 & $7.7 \%$ \\
\hline & Total & 181 & 100 \\
\hline \multicolumn{4}{|c|}{ University Year } \\
\hline \multirow{6}{*}{ Valid } & & Frequency & Percent \\
\hline & 1st year & 23 & $12.7 \%$ \\
\hline & 2nd year & 26 & $14.4 \%$ \\
\hline & 3 rd year & 33 & $18.2 \%$ \\
\hline & 4th year & 99 & $54.7 \%$ \\
\hline & Total & 181 & 100 \\
\hline \multicolumn{4}{|c|}{ Education Level } \\
\hline \multirow{5}{*}{ Valid } & & Frequency & Percent \\
\hline & Graduation & 111 & $61.3 \%$ \\
\hline & Post-graduate & 50 & $27.6 \%$ \\
\hline & Masters & 20 & $11.1 \%$ \\
\hline & Total & 181 & 100 \\
\hline \multicolumn{4}{|c|}{ Nationality } \\
\hline \multirow{4}{*}{ Valid } & & Frequency & Percent \\
\hline & Jordanian & 145 & $80.1 \%$ \\
\hline & Non-Jordanian & 36 & $19.9 \%$ \\
\hline & Total & 181 & 100.0 \\
\hline
\end{tabular}


Table 2 shows findings regarding students' perception towards the usefulness of internet in learning Englishes. According to the results, 54.8\% students agreed that English is an international language, while 50.46\% showed strongly agreed that British and American English are the major varieties of World Englishes. 58.5\% students agreed that many varieties of English exist in the world. Similarly, 55\% students agreed that non-native English speakers can also speak Standard English, and other 52\% responded that it is not important which variety of English one speaks as long as people are able to understand it. Other $44 \%$ students described World Englishes as a phrase used to describe the existence of many national and regional varieties of the English language. Besides, 39\% respondents agreed that like other varieties of English i.e. Singaporean English, Indian English, etc., Arab countries have their own variety of English. Results further indicated that for $56.35 \%$ respondents, it is not necessary to sound like a native speaker when speaking English, and other 53.03\% students felt completely fine to be identified clearly as Arabic speaker. Likewise, $61.35 \%$ students were able to identify that there is a form of English which is known as "International English".

Table 2. Perception of Students towards Use of Internet in Learning Varieties of English Language

\begin{tabular}{|c|c|c|c|c|c|}
\hline Variable & Strongly agree & Agree & Neutral & Disagree & Strongly disagree \\
\hline $\begin{array}{l}\text { English is an } \\
\text { international language. }\end{array}$ & $79(43.65)$ & $99(54.85)$ & $1(0.5)$ & $1(0.5)$ & $1(0.5)$ \\
\hline $\begin{array}{l}\text { British English and } \\
\text { American English are } \\
\text { the major varieties of } \\
\text { English in the world. }\end{array}$ & $91(50.46)$ & $80(44.19)$ & $6(3.15)$ & $2(1.10)$ & $2(1.10)$ \\
\hline $\begin{array}{llr}\text { Many } & \text { varieties of } \\
\text { English exist in the } \\
\text { world. }\end{array}$ & $54(29.85)$ & $106(58.57)$ & $16(8.84)$ & $4(2.24)$ & $1(0.5)$ \\
\hline $\begin{array}{l}\text { The non-native English } \\
\text { speakers can also speak } \\
\text { Standard English. }\end{array}$ & $53(29.03)$ & $100(55.10)$ & $20(11.5)$ & $7(3.87)$ & $1(0.5)$ \\
\hline $\begin{array}{l}\text { As long as people } \\
\text { understand me, it is not } \\
\text { important which variety } \\
\text { of English I speak. }\end{array}$ & $38(21)$ & $95(52.45)$ & $29(16.02)$ & $14(7.73)$ & $5(2.80)$ \\
\hline $\begin{array}{l}\text { "World Englishes" is a } \\
\text { phrase used to describe } \\
\text { the existence of many } \\
\text { national and regional } \\
\text { varieties of the English } \\
\text { language. }\end{array}$ & $72(40)$ & $78(44)$ & $22(12.02)$ & $7(2.88)$ & $2(1.10)$ \\
\hline $\begin{array}{l}\text { Like }- \text { Singaporean } \\
\text { English and } \text {-Indian } \\
\text { English, } \\
\text { countries have their own } \\
\text { variety } \\
\text { English: } \\
\text { English. }\end{array}$ & 71 (39) & 69 (38.3) & $27(15)$ & $12(6.6)$ & $2(1.10)$ \\
\hline $\begin{array}{l}\text { When speaking English, } \\
\text { it is not necessarily to } \\
\text { sound like a native } \\
\text { speaker. }\end{array}$ & $35(19.33)$ & $102(56.35)$ & $21(11.63)$ & $20(11.04)$ & $3(1.65)$ \\
\hline $\begin{array}{l}\text { When I speak English, it } \\
\text { is ok to be identified } \\
\text { clearly as Arabic. }\end{array}$ & $29(16.02)$ & $96(53.03)$ & $35(19.36)$ & $19(10.49)$ & $2(1.10)$ \\
\hline $\begin{array}{l}\text { There is a form of } \\
\text { English known as } \\
\text { "international English". }\end{array}$ & $41(22.65)$ & $111(61.35)$ & $19(10.49)$ & $8(4.41)$ & $2(1.10)$ \\
\hline
\end{tabular}


Students were further asked about their perceptions towards the role of internet in improving their English language skills. Table 3 shows that mostly students were of the view that the internet provides a rich learning environment $(59.67 \%)$ and that internet tools can be used for teaching purposes, as stated by $57.48 \%$ students. $40.34 \%$ of the students strongly stated that internet resources can replace textbooks. Students asserted that English websites are useful in teaching English (61.32\%). They further agreed that internet is helpful in improving their English language $(59.12 \%)$ and communication skills (60.22\%). 58.56\% students indicated that they can check grammatical correctness using internet sites, $53.60 \%$ students can check spelling mistakes, while other 50.82\% students indicated that they can improve their listening skills, and $54.14 \%$ revealed that they can know the right pronunciation of any word through internet.

Table 3. Perception of Students towards Use of Internet in Improving Their English Language Skills

\begin{tabular}{|c|c|c|c|c|c|}
\hline Variable & Strongly agree & Agree & Neutral & Disagree & Strongly disagree \\
\hline $\begin{array}{l}\text { The internet provides me as } \\
\text { a non-native speaker with a } \\
\text { rich learning environment. }\end{array}$ & $58(32.06)$ & $108(59.67)$ & $8(4.40)$ & $6(3.32)$ & $1(0.55)$ \\
\hline $\begin{array}{l}\text { Internet tools can be used } \\
\text { for teaching purposes. }\end{array}$ & $62(34.25)$ & $104(57.48)$ & $11(6.07)$ & $2(1.10)$ & $2(1.10)$ \\
\hline $\begin{array}{l}\text { Internet resources can } \\
\text { replace textbooks. }\end{array}$ & $73(40.34)$ & $47(25.97)$ & $21(11.59)$ & 34 (18.78) & $6(3.32)$ \\
\hline $\begin{array}{l}\text { English web sites are useful } \\
\text { for teaching English. }\end{array}$ & $51(28.18)$ & $111(61.33)$ & $16(8.84)$ & $2(1.10)$ & $1(0.55)$ \\
\hline $\begin{array}{l}\text { I can make my English } \\
\text { skills better through the use } \\
\text { of the Internet. }\end{array}$ & $67(37.02)$ & $107(59.12)$ & $4(2.21)$ & $2(1.10)$ & $1(0.55)$ \\
\hline $\begin{array}{l}\text { I can develop my } \\
\text { communication skills with } \\
\text { others. }\end{array}$ & $57(31.50)$ & $109(60.22)$ & $12(6.63)$ & $2(1.10)$ & $1(0.55)$ \\
\hline $\begin{array}{l}\text { I can check grammatical } \\
\text { correctness. }\end{array}$ & $67(37.02)$ & $106(58.56)$ & $6(3.32)$ & $1(0.55)$ & $1(0.55)$ \\
\hline $\begin{array}{l}\text { I can check spelling } \\
\text { mistakes. }\end{array}$ & $72(39.78)$ & $97(53.60)$ & $6(3.32)$ & $4(2.20)$ & $2(1.10)$ \\
\hline $\begin{array}{l}\text { I can make my listening } \\
\text { skills more efficient. }\end{array}$ & $77(42.54)$ & $92(50.82)$ & $6(3.32)$ & $3(1.66)$ & $3(1.66)$ \\
\hline $\begin{array}{l}\text { I can know the right } \\
\text { pronunciation of any word. }\end{array}$ & $71(39.22)$ & $98(54.14)$ & $3(1.66)$ & $6(3.32)$ & $3(1.66)$ \\
\hline
\end{tabular}

Table 4 shows regression analysis carried out for identifying the relationship between students' perceptions and the role of internet in improving the concept of World Englishes (Table 4). Findings of the study indicated an insignificant correlation between students' perceptions and the usability of internet in helping them to know English as an international language $(\mathrm{P}=222)$, in helping them to know British and American English as the major varieties of World Englishes $(\mathrm{P}=0.322)$, in understanding that many varieties of English exists $(\mathrm{P}=0.759)$ and that non-native English speakers can also speak Standard English $(\mathrm{P}=0.580)$. Similarly, an insignificant correlation was observed for the items which stated that 'The internet helps me know that as long as people understand me, it is not important which variety of English I speak $(\mathrm{P}=0.172)$ ', 'The internet helps me know that Like Singaporean English and Indian English, Arabic countries have their own variety of English: Arabic English $(\mathrm{P}=0.590)$ ', 'The internet helps me know that when speaking English, it is not necessary to sound like a native speaker $(\mathrm{P}=0.297)$ ', 'The internet helps me know that when I speak English, it is ok to be identified clearly as Arabic $(\mathrm{P}=7.99)$ ', 'The internet helps me improve my English because it provides me as a non-native speaker with a rich learning environment $(\mathrm{P}=0.411)^{\prime}$, ' $\mathrm{I}$ can make my English skills better through the use of the Internet $(\mathrm{P}=0.641)$ ', 'I can make my listening skills more efficient $(\mathrm{P}=0.246)$ ', and 'I can know the right pronunciation of any word $(\mathrm{P}=0.343)$ '.

In contrast to this, an insignificant negative correlation was identified between gender and students' perception related to the items that stated 'internet helps me to know that there is a form of English known as international English $(\mathrm{P}=0.322)$ ', 'I can develop my communication skills with others $(\mathrm{P}=0.780)$ and can check spelling mistakes $(\mathrm{P}=0.617)$.' Whereas, a significant correlation was obtained for items which states that 'Internet helps me 
know that World Englishes is a phrase used to describe the existence of many national and regional varieties of the English language $(\mathrm{P}=006)$ ', 'Internet tools can be used for teaching purposes $(\mathrm{P}=0.069)$ ', 'Internet resources can replace textbooks (0.019)', 'English web sites are useful for teaching English $(\mathrm{P}=0.001)$ '.

Table 4. Regression Analysis for the Role of Internet and Students' Perceptions of World Englishes

\begin{tabular}{|c|c|c|c|c|c|}
\hline \multicolumn{6}{|c|}{ Coefficients $^{\mathbf{a}}$} \\
\hline \multirow[t]{2}{*}{ Model } & \multicolumn{2}{|c|}{ Unstandardized Coefficients } & \multirow{2}{*}{$\begin{array}{c}\text { Standardized Coefficients } \\
\text { Beta }\end{array}$} & \multirow[t]{2}{*}{$\mathbf{t}$} & \multirow[t]{2}{*}{ Sig. } \\
\hline & B & Std. Error & & & \\
\hline (Constant) & 1.174 & .190 & & 6.174 & .000 \\
\hline $\begin{array}{l}\text { The internet helps me } \\
\text { know that English is an } \\
\text { international language. }\end{array}$ & .089 & .072 & .119 & 1.228 & .222 \\
\hline $\begin{array}{l}\text { The internet helps me } \\
\text { know that there is a form } \\
\text { of English known as } \\
\text { "international English". }\end{array}$ & -.004 & .055 & -.008 & -.068 & .946 \\
\hline $\begin{array}{l}\text { The internet helps me } \\
\text { know that British English } \\
\text { and American English are } \\
\text { the major varieties of } \\
\text { English in the world. }\end{array}$ & .047 & .047 & .107 & .995 & .322 \\
\hline $\begin{array}{l}\text { The internet helps me } \\
\text { know that many varieties } \\
\text { of English exist in the } \\
\text { world. }\end{array}$ & .019 & .060 & .033 & .308 & .759 \\
\hline $\begin{array}{l}\text { The internet helps me } \\
\text { know that the non-native } \\
\text { English speakers can also } \\
\text { speak Standard English. }\end{array}$ & .025 & .045 & .053 & .555 & .580 \\
\hline $\begin{array}{l}\text { The internet helps me } \\
\text { know that as long as } \\
\text { people understand me, it is } \\
\text { not important which } \\
\text { variety of English I speak. }\end{array}$ & .053 & .038 & .136 & 1.374 & .172 \\
\hline $\begin{array}{l}\text { The internet helps me } \\
\text { know that" World } \\
\text { Englishes" is a phrase } \\
\text { used to describe the } \\
\text { existence of many } \\
\text { national and regional } \\
\text { varieties of the English } \\
\text { language. }\end{array}$ & .168 & .060 & .310 & 2.793 & .006 \\
\hline $\begin{array}{l}\text { The internet helps me } \\
\text { know that Like } \\
\text { Singaporean English and } \\
\text { Indian English, Arabic } \\
\text { countries have their own } \\
\text { variety of English: Arabic } \\
\text { English. }\end{array}$ & .029 & .053 & .062 & .541 & .590 \\
\hline $\begin{array}{l}\text { The internet helps me } \\
\text { know that when speaking } \\
\text { English, it is not necessary }\end{array}$ & -.044 & .042 & -.107 & -1.048 & .297 \\
\hline
\end{tabular}


to sound like a native

speaker.

The internet helps me know that when I speak English, it is ok to be identified clearly as Arabic.

The internet helps me improve my English because it provides me as a non-native speaker with a rich learning environment.

Internet tools can be used for teaching purposes.

Internet resources can replace textbooks.

English web sites are useful for teaching English.

I can make my English skills better through the use of the Internet.

I can develop my communication skills with others.

I can check grammatical correctness.

I can check spelling mistakes.

I can make my listening skills more efficient.

I can know the right pronunciation of any word.$$
.011
$$

a. Dependent Variable: Students' Perceptions of World Englishes

\section{Discussion}

Being lingua franca, English language plays a significant role in almost every aspect of life; it helps us to enhance educational competence and also to communicate effectively with people all over the world. The current study identified Jordanian university students' perceptions regarding the role of internet in developing their understanding of World Englishes, and improving their language skills.

Findings of the study indicated that most of the students agreed that internet is useful in helping them to develop English language skills, and understanding the concept of Englishes. They further favored internet as a useful means of providing a good and resourceful learning environment for learners. These results are in line with the study of Sutherland (2011), according to which online news services provide radio broadcasts on their web pages, independent producers let viewers watch short films, movies, etc. A sensible selection of material can provide a direct experience of several forms of English pronunciation to students. Lin and Yang (2011) also supported the findings of the current study and highlighted that students' writing skills can be improved by utilizing internet as an efficient learning and teaching resource as students can write passages on any application to enhance their reading and writing skills related to the English language. 
Similar results were provided in the study of Peregoy, Boyle and Martinez (2011) as they identified improvement in students' reading and writing skills with the use of online resources. Findings of this study affirmed that students learn more effectively when they are taught through online resources rather than traditional teaching methods as internet is considered as a preferable medium of language learning. Identifying varieties of World Englishes is important to make English language pedagogy accessible and viable (Bhowmik, 2015).

Findings of the current study further indicated that English websites are useful tools to be used for teaching English. These findings are supported by the study of Matsuda (2012), according to which teaching materials should not be restricted to the published material only, as advanced instructional methods, such as those available on the internet are very effective in providing students highly useful and diverse learning resources. For instance, newspaper articles from three circles are available on the internet and may be used as an authentic reading material for classroom discussion. In addition, video clips available on YouTube and other broadcasting stations may expose students to other online audio or video-based channels showing samples of World Englishes (Mauranen, 2018; Dovchin, 2017).

Moreover, most of the respondents of the current study showed their agreement regarding the usefulness of internet-based resources as a replacement of textbooks. This means students are willing to integrate the online resources in everyday language classrooms. This strategy would help them learn through a variety of resources, and ultimately motivates them to learn more. These results are supplemented by the findings of the study of Wong (2011), who identified that teachers need to deliver language related instructions through different resources following the perspective of World Englishes. However, the idea seemed to be valid in the case of this study in which Wong (2011) revealed positive perceptions of Taiwanese students towards learning Indian English on account of its usage in the classroom-based lectures.

Findings of the current study further indicated that internet serves as a significant source to be used in the development of understanding the differences in the language when communicating to other native speakers. Also, most of the students showed positive perceptions regarding the concept of WE and the usability of internet in enhancing their understanding regarding English language skills. These findings are supported by Aydin (2007) who emphasized on the role of internet in the process of language learning. According to the study findings, most of the EFL learners had a positive attitude towards language learning through internet. This observation further indicated the growing interest of learners towards the use of internet (Jamalifar \& Chalak, 2014; Lin, 2009). The information obtained from internet/websites helps students to comprehensively classify different varieties of World Englishes and to re-discover new features. It is probable to access aural materials on the internet with reasonably updated media devices (Tamandani \& Jahanshahi, 2016).

Respondents of the current study further indicated that the use of internet is beneficial for students in learning language related skills: communication skills, writing skills, listening skills and learning skills. These results are supported by the findings of Cahyono and Mutiaraningrum (2016), according to which, students who are taught through internet-based techniques showed significant improvements in their writing skills (Aliyev \& Ismayilova, 2017). It further indicated that most of the students reflected positive perceptions regarding the use of internet in developing language related skills (Cahyono \& Mutiaraningrum, 2016). For Noytim (2010), usefulness of online blogs is also considerable which motivate students to express their thoughts and also enhances their writing skills. Similarly, Hismanoglu and Hismanoglu (2011) supported the idea of using internet-based English language teaching as it eases the articulation of difficult words of the English language. The approach is specifically beneficial for students who faced problems in the articulation of English language. Benmeddah (2017) added that online sources such as Facebook, Skype, and YouTube provide online resources to students that help them understand World Englishes via their meaningful interactions with students of other parts of the world who speak different varieties of English language.

\section{Implications}

Findings of the current study has important implications regarding the improvement in the existing educational standards of the Jordanian Ministry of Higher Education and Jordanian public and private universities. As evident from the findings of the current study, most of the students consider learning World Englishes through internet as an appropriate option; therefore, Ministry of Higher Education of Jordan should make efforts to improve the existing curriculum of English language implemented in Jordanian universities to cater the needs of the university students. The above discussion can be used to make improvement in teaching and learning pedagogies, specifically in learning domain where students face several challenges. The study findings also help to identify the role of teacher in understanding the use of flexible resources in the development of different language skills. Finally, academicians may implement the study findings by making flexible and interesting changes in their contemporary learning methods, while realizing the usefulness of online available resources. 


\section{Limitations}

The current study has certain limitations. In the first place, a small sample size was used for data collection which may affect the generalizability of the study findings. Another limitation of the study is that the existing curriculum of students was not being analyzed to make further arguments regarding the extent of success of universities in directing students towards the usability of online learning resources. In the light of these facts, future researchers are suggested to conduct a correlation study to identify the relationship between learners' attitude and responsiveness towards use of technology for language learning.

\section{Conclusion}

The current study examined the perceptions of Jordanian University students towards the role of internet in improvement of their understanding of World Englishes and development of their language skills. The findings of this study indicated positive perception of students regarding the usefulness of internet in providing them the opportunity to explore variation in English language. The above discussion further indicated that most of the students felt motivated to use internet as the source of learning, and further indicated their tendency to replace conventional textbooks. It is noteworthy that the usefulness of internet is only perceived important for students; however, teachers may also use it as an important tool to enhance their English language teaching.

The use of internet-based learning resources is effective in optimizing the language learning process as it provides greater possibilities for both students and teachers to make learning process effective and interesting. Students' positive perceptions towards the use of internet for learning World Englishes and related language skills will help them become competent individuals ready to meet the needs of the professional world. Websites provide a wide range of opportunities to students to share information, develop their own content, and communicate all over the world. This also implies that they give their best to seize every possible chance to increase their knowledge using internet. Internet can help increase encouragement and achievement of students by affecting their perception and helping them feel more independent. In general, the technology has the accepted potential for promoting learners' English language skills and motivation towards World Englishes, while, at the same time, strengthening their linguistic skills, developing their self-instruction strategies and self-confidence, and affecting their learning attitude.

Since internet is considered as one of the most frequently used platforms of communication and interaction, more lectures on World Englishes and localized Englishes should be promoted on internet to produce more confident English users. Full-fledged research works have to be conducted for the description of Jordan English and its variety that is being used by educated Jordanian English speakers. More opportunities should be provided to them to confidently use the language even with native Jordanian features with an aim to improve English language communication of Jordanian people.

\section{Funding}

This study is self-funded.

\section{Acknowledgement}

The author is very thankful to all the associated personnel in any reference that contributed in/for the purpose of this research. Further, this research holds no conflict of interest and is not funded through any source.

\section{Conflicts of Interest}

The authors declare no conflict of interest.

\section{References}

AbuSa'aleek, A. O. (2015). Internet linguistics: A linguistic analysis of electronic discourse as a new variety of language. International Journal of English Linguistics, 5(1), 135. https://doi.org/10.5539/ijel.v5n1p135

Aiello, J. (2017). Negotiating Englishes and English-speaking identities: A study of youth learning English in Italy. Taylor \& Francis. https://doi.org/10.4324/9781315299679

Al-Dosari, H. S. (2011). An Investigation of Attitudes towards Varieties of Spoken English in a Multi-lingual Environment. Theory \& Practice in Language Studies, 1(9). https://doi.org/10.4304/tpls.1.9.1041-1050

Aliyev, A., \& Ismayilova, K. (2017). Improving English writing skills of non-native undergraduate learners with the help of movies supported by online technologies. Journal of Education in Black Sea Region, 2(2), 2-16. https://doi.org/10.31578/jebs.v2i2.38

Al-Kadi, A. M. T., \& Ahmed, R. A. (2018). Evolution of English in the internet age. Indonesian Journal of Applied Linguistics, 7(3), 727-736. https://doi.org/10.17509/ijal.v7i3.9823 
Alomoush, O. I. S. (2019). English in the linguistic landscape of a northern Jordanian city: Visual monolingual and multilingual practices enacted on shopfronts. English Today, 35(3), 35-41. https://doi.org/10.1017/s0266078418000391

Anwar, K., Ubaidillah, M. F., Tarrayo, V. N., Ismiatun, F., Khotimah, K., Irawansyah, I., \& Sulistiyo, U. (2020). Orientations in learning English as a foreign language: How do Indonesian students view them? EduLite: Journal of English Education, Literature and Culture, 5(1), 32-42. https://doi.org/10.30659/e.5.1.32-42

Armstrong, K. M., \& Yetter-Vassot, C. (1994). Transforming teaching through technology. Foreign Language Annals, 27(4), 475-486. https://doi.org/10.1111/j.1944-9720.1994.tb01225.x

Aydin, S. (2007). Attitudes of EFL learners towards the Internet. Turkish Online Journal of Educational Technology-TOJET, 6(3), 18-26.

Baik, M. J., \& Shim, R. J. (2002). Teaching World Englishes via the Internet. World Englishes, 21(3), 427-30. https://doi.org/10.1111/1467-971X.00260

BENMEDDAH, W. (2017). The Use of ICT in Developing the Speaking Skill in EFL Classes: Case of First Year EFL Students at the University of Tlemcen (Doctoral dissertation).

Butler-Pascoe, M. E., \& Wiburg, K. M. (2003). Technology and teaching English language learners. Pearson College Division.

Cahyono, B. Y., \& Mutiaraningrum, I. (2016). Indonesian EFL Teachers' Familiarity with and Opinion on the Internet-Based Teaching of Writing. English Language Teaching, 9(1), 199-208. https://doi.org/10.5539/elt.v9n1p199

$\begin{array}{lllll}\text { Cambridge } & \text { Dictionary. } & \text { (n.d). } & \text { Perception. } & \text { Retrieved }\end{array}$ https://dictionary.cambridge.org/dictionary/english/perception

Cheshire, J. (Ed.). (1991). English around the World: Sociolinguistic perspectives. Cambridge University Press. https://doi.org/10.1017/CBO9780511611889

Collot, M., \& Belmore, N. (1996). A new variety of English. Computer-mediated communication: Linguistic, social, and cross-cultural perspectives, 39, 13. https://doi.org/10.1075/pbns.39.04col

Costley, K. C. (2014). The Positive Effects of Technology on Teaching and Student Learning. Online Submission.

Crystal, D. (2011). Internet linguistics: A student guide. Routledge. https://doi.org/10.4324/9780203830901

Davis, B. H., Brewer, J., \& Brewer, J. P. (1997). Electronic discourse: Linguistic individuals in virtual space. Suny Press.

Dovchin, S. (2017). The role of English in the language practices of Mongolian Facebook users: English meets Mongolian on social media. English Today, 33(2), 16-24. https://doi.org/10.1017/s0266078416000420

Drbseh, M. M. H. (2013). The spread of English language in Jordan. International Journal of Scientific and Research Publications, 3(9), 1-5.

Ergenekon, B. (2016). Using Films for Writing Reaction-Response Essay: A Class-Room Action Research on Turkish ESP Learners. International Journal of Languages, Literature and Linguistics, 2(2), 73-78. https://doi.org/10.18178/ij1ll.2016.2.2.70

Farrell, T. S., \& Martin, S. (2009). To Teach Standard English or World Englishes? A Balanced Approach to Instruction. In English Teaching Forum (Vol. 47, No. 2, pp. 2-7). US Department of State. Bureau of Educational and Cultural Affairs, Office of English Language Programs, SA-5, 2200 C Street NW 4th Floor, Washington, DC 20037.

Galloway, N. (2017). Global Englishes and change in English language teaching: Attitudes and impact. Taylor \& Francis. https://doi.org/10.4324/9781315158983

Galloway, N., \& Rose, H. (2018). Incorporating Global Englishes into the ELT classroom. ELT Journal, 72(1), 3-14. https://doi.org/10.1093/elt/ccx010

Gilakjani, A. P. (2017). A review of the literature on the integration of technology into the learning and teaching of English language skills. International Journal of English Linguistics, 7(5), 95-106. https://doi.org/10.5539/ijel.v7n5p95

Hamdan, J. M., \& Hatab, W. A. A. (2009). English in the Jordanian context. World Englishes, 28(3), 394-405. https://doi.org/10.1111/j.1467-971X.2009.01599.X 
Heirati, J. K., \& Alashti, L. A. (2015). Attitudes toward using the Internet for language learning: A case of Iranian English teachers and learners. International Journal of Research Studies in Educational Technology, 4(1). https://doi.org/10.5861/ijrset.2015.1029

Herring, S. C. (Ed.). (1996). Computer-mediated communication: Linguistic, social, and cross-cultural perspectives (Vol. 39). John Benjamins Publishing. https://doi.org/10.1075/pbns.39

Herrmann, T. (2003). Relative clauses in dialects of English. A typological approach (Doctoral dissertation, Albert-Ludwigs-Universität, Freiburg i. Br.).

Hickey, R. (1999). Dublin English: Current changes and their motivation. Urban voices: Accent studies in the British Isles, 265-281.

Hickey, R. (2010). The Englishes of Ireland. The Routledge Handbook of World Englishes, 76.

Hickey, R. (n.d). Englishes in England, Scotland, Wales, and Ireland. University of Duisburg and Essen. Retrieved from https://www.uni-due.de/ELE/English_Varieties_in_Britain_and_Ireland_(Hickey).pdf

Hinkel, E. (Ed.). (2011). Handbook of research in second language teaching and learning. Routledge. https://doi.org/10.4324/9780203836507

Hismanoglu, M., \& Hismanoglu, S. (2011). Internet-based pronunciation teaching: An innovative route toward rehabilitating Turkish EFL learners' articulation problems. European Journal of Educational Studies, 3(1), 23-36. https://doi.org/10.1016/j.sbspro.2011.03.049

Ito, T. A., \& Cacioppo, J. T. (2007). Attitudes as Mental and Neural States of Readiness: Using Physiological Measures to Study Implicit Attitudes.

Jamalifar, G., \& Chalak, A. (2014). The Use of Internet in English Language Learning: Practices, Attitudes and Challenges of the Learners. Advances in English Language and Literature (AELL), 1(2), 1-6.

Kachru, B. B. (1997). World Englishes 2000: Resources for research and teaching. Literary Studies, 14, $209-251$.

Kachru, Y. Contexts and Relevance for Language Education. Handbook of Research in Second Language Teaching and Learning, 155.

Khotimah, K., Dewi, C. T. K., Ulum, S., \& Putra, M. F. P. (2015). Darkness in Edgar Allan Poe's A Dream within A Dream. https://doi.org/10.5539/ijel.v5n5p159

Kilickaya, F. (2009). World Englishes, English as an International Language and Applied Linguistics. English Language Teaching, 2(3), 35-38. https://doi.org/10.5539/elt.v2n3p35

Kirkpatrick, A. (Ed.). (2010). The Routledge handbook of world Englishes. Routledge. https://doi.org/10.4324/9780203849323

Kissau, S. P., Algozzine, B., \& Yon, M. (2012). Similar but different: The beliefs of foreign language teachers. Foreign Language Annals, 45(4), 580-598. https://doi.org/10.1111/j.1944-9720.2013.12001.X

Kumar Bhowmik, S. (2015). World Englishes and English Language Teaching: A pragmatic and humanistic approach. Colombian Applied $\quad$ Linguistics $\quad$ Journal, 17(1), https://doi.org/10.14483/udistrital.jour.calj.2015.1.a10

Lee, J. S. (2019). Teacher as change agent: Attitude change toward varieties of English through teaching English as an international language. Asian $\quad$ Englishes, 21(1), https://doi.org/10.1080/13488678.2018.1434396

Lee, Y. H., \& Jun, K. S. (2016, October). The Inner Circle vs. the Outer Circle or British English vs. American English. In Proceedings of the 30th Pacific Asia Conference on Language, Information and Computation: Posters (pp. 339-346).

Lin, L. L. (2009). Technology and Second Language Learning. Online Submission.

Lin, W. C., \& Yang, S. C. (2011). Exploring students' perceptions of integrating Wiki technology and peer feedback into English writing courses. English Teaching: Practice and Critique, 10(2), 88-103. https://doi.org/10.22158/selt.v4n3p351

Lyddy, F., Farina, F., Hanney, J., Farrell, L., \& Kelly O’Neill, N. (2014). An analysis of language in university students' text messages. Journal of Computer-Mediated Communication, 19(3), 546-561. https://doi.org/10.1111/jcc4.12045 
Maftoon, P., \& Esfandiari, L. T. (2013). World Englishes and linguistic imperialism: Implications in ELT. The International Journal of Language Learning and Applied Linguistics World, 35.

Mahboob, A. (2013). Englishes of the Middle East: A focus on the Kingdom of Saudi Arabia. Middle East handbook of applied linguistics, 1, 14-27.

Matsuda, A. (2012). World Englishes and teaching English to speakers of other languages. The encyclopedia of applied linguistics, 1-7. https://doi.org/10.1002/9781405198431.wbeal1293

Matsuda, A. (2018). World Englishes and NNESTs. The TESOL encyclopedia of English language teaching, 1-6. https://doi.org/10.1002/9781118784235.eelt0041

Matsuda, A. (2019). World Englishes and pedagogy. The handbook of world Englishes, 686-702. https://doi.org/10.1002/9781119147282.ch38

Matsuura, H., Chiba, R., \& Fujieda, M. (1999). Intelligibility and comprehensibility of American and Irish englishes in Japan. World Englishes, 18(1), 49-62. https://doi.org/10.1111/1467-971x.00121

Mauranen, A. (2018). Second language acquisition, world Englishes, and English as a lingua franca (ELF). World Englishes, 37(1), 106-119. https://doi.org/10.1111/weng.12306

Merriam Webster. (n.d). Perception. Retrieved from https://www.merriam-webster.com/dictionary/perception

Molchanova, I. I. (2015). Influence of the Internet on Studying English. International Education Studies, 8(1), 133-141. https://doi.org/10.5539/ies.v8n1p133

Montes, A. L. G. (2016). English in Brazil: A sociolinguistic profile. Journal of Pedagogy, Pluralism, and Practice, $8(1), 30$.

Mustafa, H. R., Sain, N., \& Razak, N. Z. A. (2012). Using Internet for learning vocabulary among second language learners in a suburban school. Procedia-Social and Behavioral Sciences, 66, 425-431. https://doi.org/10.1016/j.sbspro.2012.11.286

Noels, K., Clément, R., \& Pelletier, L. (2001). Intrinsic, extrinsic, and integrative orientations of French Canadian learners of English. Canadian Modern Language Review, 57(3), 424-442. https://doi.org/10.3138/cmlr.57.3.424

Noytim, U. (2010). Weblogs enhancing EFL students' English language learning. Procedia-Social and Behavioral Sciences, 2(2), 1127-1132. https://doi.org/10.1016/j.sbspro.2010.03.159

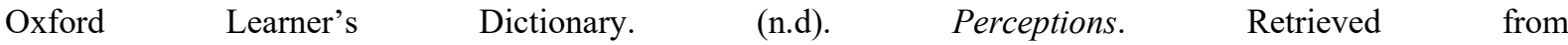
https://www.oxfordlearnersdictionaries.com/definition/english/perception

Peitsara, K., \& Vasko, A. L. (2002). The Helsinki Dialect Corpus: characteristics of speech and aspects of variation. Helsinki English Studies, The Electronic Journal of the Department of English at the University of Helsinki, 2.

Peregoy, S. F., Boyle, O. F., \& Martinez, G. (2011). Reading, Writing, and Learning in ESL: A Resource Book for Teaching K-12 English Learners. TESOL Journal, 2(1), 119-120. https://doi.org/10.5054/tj.2011.244400

Petrovskaya, T. S., \& Rymanova, I. E. (2014). Motivacija izuchenija anglijskogo jazyja studentami tehnicheskogo vuza pri smeshannom obuchenii (Motivation for Studying the English Language by Students of Technical Higher Education Establishment by Blended Learning). Filologicheskie nauki. Voprosy teorii $i$ praktiki, 7(37), 152-154.

Rousseau, P. (2012). A World Englishes study of Korean university students: Effects of pedagogy on language attitudes.

Sarnoff, I. (1970). Social attitudes and the resolution of motivational conflict. Attitudes. Harmondsworth: Penguin, 271-282.

Seargeant, P., \& Tagg, C. (2011). English on the internet and a 'post-varieties' approach to language. World Englishes, 30(4), 496-514. https://doi.org/10.1111/j.1467-971x.2011.01730.x

Singhal, M. (1997). The Internet and foreign language education: Benefits and challenges. The internet TESL journal, 3(6), 107.

Smith, L. E., \& Nelson, C. L. (2019). World Englishes and issues of intelligibility. The handbook of world Englishes, 430-446. https://doi.org/10.1002/9781119147282.ch24 
Sun, H. M. (2010). A study of the features of internet English from the linguistic perspective. Studies in Literature and Language, 1(7), 98-103.

Sutherland, S. (2011). World Englishes on the Internet: some considerations for teaching. Sino-US English Teaching, 8(5), 322-326.

Syawal, S., Patahuddin, P., \& Nasrullah, N. (2017). The Effect of Internet on English Learners' Learning Behavior. ELT WORLDWIDE, 4(2), 171-179.

Tahmasbi, S., Hashemifardnia, A., \& Namaziandost, E. (2019). Standard English or world Englishes: Issues of ownership and preference. Journal of Teaching English Language Studies, 7(3), 83-98.

Tajfel, H., Turner, J. C., Austin, W. G., \& Worchel, S. (1979). An integrative theory of intergroup conflict. Organizational identity: A reader, 56, 65. https://doi.org/10.4324/9780203505984-16

Tamandani, K. K., \& Jahanshahi, M. (2016). Using E-learning Techniques and Tools for Enhancing Main English Language Skills. International Journal for Teachers of English, 4, 44-51.

Thurlow, C. (2001). The Internet and language. Concise Encyclopedia of Sociolinguistics; Mesthrie, R., Asher, R., Eds., 287-289.

Todd, R. W. (2006). The myth of the native speaker as a model of English proficiency. Reflections, 8, 1-7.

Tokumoto, M., \& Shibata, M. (2011). Asian varieties of English: Attitudes towards pronunciation. World Englishes, 30(3), 392-408. https://doi.org/10.1111/j.1467-971x.2011.01710.x

Ugoretz, K. (2016). China English: A developing, functional, and legitimate world English variety. SINO-PLATONIC PAPERS, 123.

Widdowson, H. G. (1994). The ownership of English. TESOL quarterly, 28(2), 377-389. https://doi.org/10.2307/3587438

Widdowson, H. G. (1997). EIL, ESL, EFL: Global issues and local interests. World Englishes, 16(1), 135-146. https://doi.org/10.1111/1467-971X.00054

Yan, J. X., \& Horwitz, E. K. (2008). Learners' perceptions of how anxiety interacts with personal and instructional factors to influence their achievement in English: A qualitative analysis of EFL learners in China. Language learning, 58(1), 151-183. https://doi.org/10.1111/j.1467-9922.2007.00437.x

Yoshida, R. (2008). Learners' perception of corrective feedback in pair work. Foreign Language Annals, 41(3), 525-541. https://doi.org/10.1111/j.1944-9720.2008.tb03310.x

Yu, Y. (2010). Attitudes of Learners toward English: A Case of Chinese College Students. (Presented in Partial Fulfillment of the Requirements for the Degree Doctor of Philosophy in the Graduate School of The Ohio State University).

\section{Copyrights}

Copyright for this article is retained by the author(s), with first publication rights granted to the journal.

This is an open-access article distributed under the terms and conditions of the Creative Commons Attribution license (http://creativecommons.org/licenses/by/4.0/). 